\author{
Sergei M. BOSIAKOV ${ }^{1}$ \\ Denis V. ALEKSEEV ${ }^{2}$ \\ Ihar E. SHPILEUSKI ${ }^{3}$ \\ Vadim V. SILBERSCHMIDT ${ }^{4}$ \\ Feliks STACHOWICZ ${ }^{5}$ \\ Tomasz TRZEPIECIŃSKI ${ }^{6}$
}

\title{
FORMATION OF MICROCRACKS NEAR SURGICAL DEFECT IN FEMUR: ASSESSMENT OF ULTIMATE LOADING CONDITIONS
}

\begin{abstract}
A bone defect of rectangular shape in a femur is considered as a result of a surgical resection of tumor lesions. Based on finite-element calculation of J-integral near the bone defect, ultimate combinations of loads corresponding to formation of microcracks were determined. The loads corresponds to simultaneous actions of own human's weight, flexion-extension, adduction-abduction and rotation of the femur. Recommendations for the prevention of pathological fractures of the femur with the surgical defect based on the obtained results were formulated.
\end{abstract}

Keywords: surgical resection, compact bone, J-integral, microcracks, combined loading

\section{Introduction}

The main method of treatment of benign tumours and metastatic lesions of long bones is a surgical removal of the affected area within an unmodified tissue (surgical resection). After surgery, as shown in Figure 1, a sectoral defect of rectangular shape is formed in the bone. As a result, bone strength and functionality of the operated limb decrease and the risk of pathologic fracture of the surgical resection increases.

\footnotetext{
1 Autor do korespondencji/corresponding author: Sergei Bosiakov, Belarusian State University, Nezavisimosti 4, 220030 Minsk, Belarus, e-mail: bosiakov@bsu.by

2 Denis V. Alekseev, Belarusian State University, e-mail: onardeon@gmail.com

${ }^{3}$ Ihar E. Shpileuski, Republican Scientific and Practical Centre for Traumatology and Orthopedics, Minsk, Belarus, e-mail: ihar@gmail.com

${ }^{4}$ Vadim V. Silberschmidt, Loughborough University, UK, e-mail: V.Silberschmidt@lboro.ac.uk

${ }^{5,6}$ Feliks Stachowicz, Tomasz Trzepieciński, Rzeszow University of Technology, Poland, e-mails: stafel@prz.edu.pl, tomtrz@prz.edu.pl
} 
Clinical and radiological criteria of the possibility of loading long bones and the magnitude of the ultimate load on the operated extremity are developed in sufficient detail. However, practical recommendations on compensation of a bone strength loss and the prevention of pathological fracture after a sectoral resection (load limitation, bone reinforcement or external immobilization) are exclusively descriptive.

a)

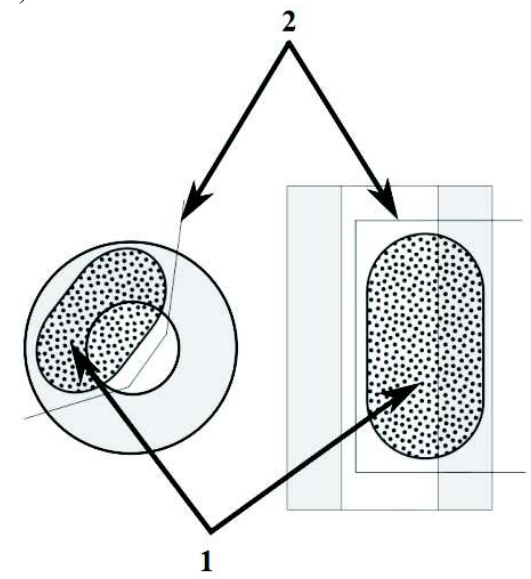

b)

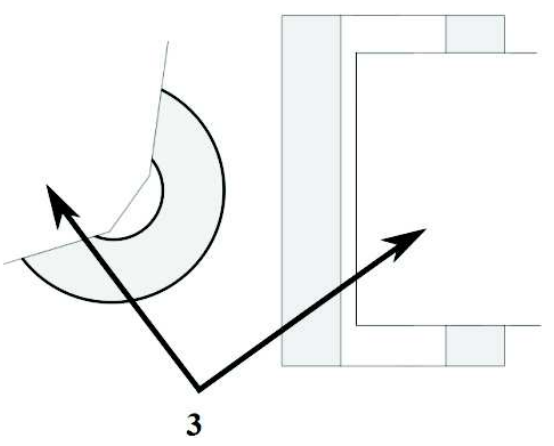

Fig. 1. Scheme of femoral resection: a - fragment of cortical bone before surgical resection (1 - lesion, 2 -line of bone excision), $b$ - fragment of cortical bone after resection (3 - post-resection defect)

A retrospective research of bone functioning and assessment of its fracture risk after a surgical resection of a humerus was performed in [19]. The authors concluded that pathological fractures of the distal humerus were rare and associated with repeated operations; for the prevention of fractures in a proximal region and diaphysis, the use of pros-thesis and fixation, respectively, were suggested. At the same time, development of practical recommendations for the prevention of pathologic fractures after a surgical resection is a fundamental issue, since a restriction of a functional load on an operated limb reduces significantly the patient's ability for self-care and mobility (especially in a case of a lower extremity). Reinforcement of a bone at the level of surgical resection (preventive fixation) can compensate for the loss of strength of the affected segment more fully and minimize a decline in the quality of life; however, this method needs re-intervention to remove the fixation. Development of recommendations on a use of different methods to compensate the loss of bone strength and prevent pathological fracture after a sector resection is required to avoid excessive treatment. Similar recommendations for the prevention of pathological fractures of bone with metastases and tumors took into account a size of the lesion, damage to cortical bone, results of radiographic examination, as well as an increase 
in local pain $[6,8,12]$. A scoring system combining radiographic and clinical factors into a single indicator to predict impending fracture was proposed. These approaches were subjected to some criticism in [4] and [18]. Moreover, the authors of these studies stated that indications for prophylactic fixation of impending fractures of long bones were not defined rigorously. So, it is necessary to perform additional research and formulate more stringent criteria for prediction of the risk of potential fractures of long bones with metastatic lesions.

Finite-element (FE) modelling is the most appropriate method for suggestion of objective indicators for the prevention of fractures after surgical resection of bones. This approach is currently widely used for prediction of fractures and corresponding loads as well as localization of fracture in femur under different loading conditions; important results in this area are described in $[1,2,9,10,13$, 14]. Assessments of fracture risk and definition of a failure load for bones with metastatic lesions based on the finite-element method were carried out in $[3,5$, $7,15,16]$. In a study on prediction of fracture load and objective assessment of the failure of femur with lytic defects [11], an engineering theory of beams was used in conjunction with tomographic data on structural stiffness. Basically, FE modelling and corresponding experimental verification were carried out for femurs with metastatic lesions of round or oval shape $[3,7,11,16]$. FE simulations of femurs with rectangular-shaped defects were carried out in [5] and [15]. A maximum width of defects in these studies was assumed to be equal to 0.3 [5] and 0.25 [15] of an external diameter of the bone. Rectangular concentrators due to defect corners were examined in [5]. These concentrators were with the right angles [5] or with rounded edges [15]. The mentioned geometric dimensions of defects do not correspond fully to cuts formed after a sectoral resection; an angular size of post-resection defects can reach $3 \pi / 2$. Another important feature of post-resection defects is formation of notches in defect's corners after a use of cutting tools. Such notches have a significant effect on development of cracks in a bone.

a)

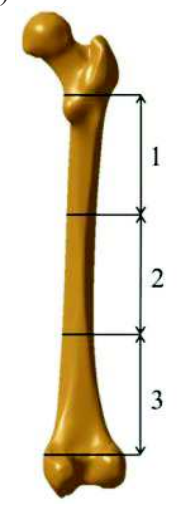

b)

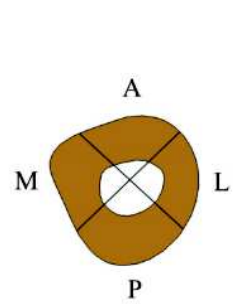

Fig. 2. (a) Three parts of femur diaphysis (posterior view): 1 - top part, 2 - middle part, 3 - bottom part; (b) cross-section of femur in middle part: $\mathrm{A}$ - anterior side, $\mathrm{M}$ medial side, $\mathrm{P}$ - posterior side, $\mathrm{L}$ lateral side 
The aim of this study is the FE-based prediction of ultimate loading combinations that could be applied to a femur with a post-resection defect exposed to combinations of the human's own weight and flexion-tension, adductionabduction or rotation. The bone defect was considered to be in the medial section of the femur on its medial side. Three main parts of the femur and its different cortices are shown in Figure 2. Recommendations to prevent excessive treatment of patients after surgical resection are formulated on the basis of FE calculations of J-integral and experimental results [20]. These recommendations, primarily, may refer to the description of the unloading regime conditions for patients after surgical resections.

\section{FE modelling of femur loading}

Computed tomography of a femur was carried out with a spiral X-ray Tomograph (Siemens Somatom Emotion 16) with a slice step of $2.0 \mathrm{~mm}$, and its three-dimensional solid model was obtained by using a computer system of medical image processing ScanIP (Simpleware Ltd., UK). A STL-model was converted into a solid model with CATIA V5 (Dassault Systemes, France). A bone tissue was modelled as a homogeneous transversally isotropic material [1]. Lower sections of the femoral condyles (regions of contact with the condyles of the tibia) were fixed rigidly. The bone defect's length was $64 \mathrm{~mm}$, its angular size was 1800 , and the bone defect was located in the femur's middle third on its medial side.

The loads in the model were applied in accordance with the location of the biomechanical $z_{1}$-axis and anatomical $z_{2}$-axis. Point $\mathrm{O}_{1}$ (see Figure 3 ) was the center of the head of the femur; point $\mathrm{O}_{2}$ was a trochanteric fossa point, point $\mathrm{O}$ was located in the center between the two lower condyles. The human's own weight was applied along the $z_{l}$-axis to one-third of the area of the femur head. A bending moment for flexion-tension acted in the $\mathrm{y} z_{1}$-plane ( $y$-axis was parallel to the plane tangent to the condyles of the lower joint). A bending moment for abduction-adduction acted in the $\mathrm{x} z_{l}$-plane ( $x$-axis was perpendicular to the yz1plane). A torsion torque was applied in $\mathrm{O}_{2}$; distance between point $\mathrm{O}_{2}$ and biomechanical axis was an arm for the torsion torque of the femur. The used coordinate systems $x_{0} z_{1}$ and $x 0 z_{2}$ are shown in Figure 3. The biomechanical and anatomical axes and the characteristic point were embedded in accordance with recommendations from $[21,22]$. In the corners of the post-resection defect, predefined cracks were located in order to calculate values of $j$-integrals (see Figure 4). The bone was meshed with maximum size of the element $5 \mathrm{~mm}$. Meshes of domains near the corners of the cutting defect were refined (the element size was $0.1 \mathrm{~mm}$ ) and mapped to achieve higher uniformity. The finite-element model of the femur region with concentrators of the post-resection defect is shown in Figure 4. 
a)

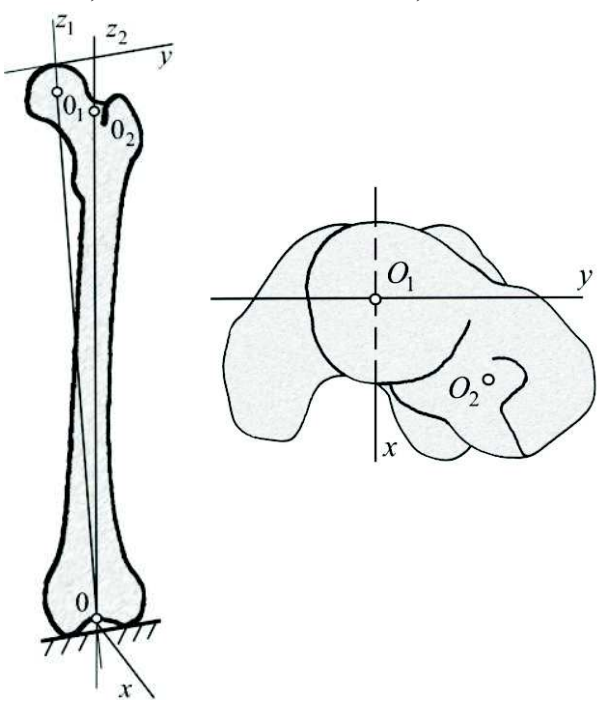

b)
Figure 3. Top $(a)$ and side $(b)$ view of femur with local coordinate systems; the $z_{1}$-axis and $z_{2}$-axis are the biomechanical and anatomical axes, respectively; $y$ axis is parallel to the plane tangent to the condyles of the lower joint; the $x$-axis is perpendicular to the $y z l$-plane. Point $\mathrm{O}_{1}$ is the center of the head of the femur, point $\mathrm{O}_{2}$ is a trochanteric fossa point; point $\mathrm{O}$ is located in the center between the two lower condyles

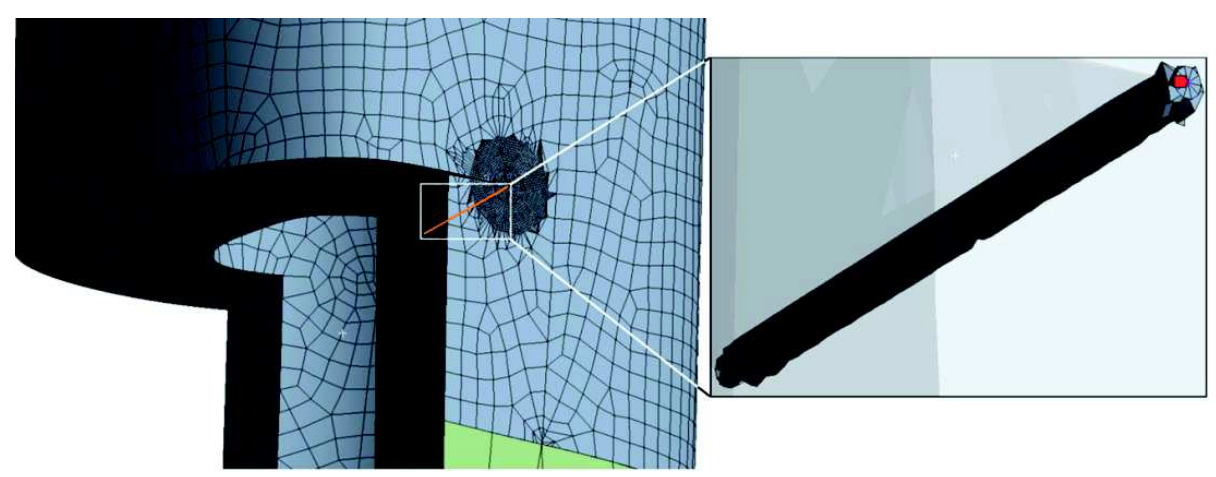

Fig. 4. Finite-element model of femur in middle third of diaphysis (defect length 2d, angular size 1800 , length of pre-defined crack for calculations of J-integrals is $3 \mathrm{~mm}$. A zoomed-in part shows finite elements along the crack front

\section{Ultimate load combinations}

Assessment of ultimate loading conditions for the post-resection bone defect was carried out using the critical value of $J$-integral corresponding to onset of crack propagation obtained in the experiment [20]. The critical $J$-integral was equal approximately to $5925 \mathrm{~N} / \mathrm{m}$ [20]. Ultimate load combinations corresponded to such combinations of simultaneously applied loads that lead to the critical value of $J$-integral. Several types of load combinations were considered, namely, the human's own weight $P$ together with the flexion-tension moment $T_{\mathrm{f}-\mathrm{t}}$, the adduction-abduction moment $T_{\mathrm{a}-\mathrm{a}}$ or the torque $T_{\mathrm{r}}$. Figure 5 presents the curves 
corresponding to such ultimate load combinations in coordinates $\left(T_{\mathrm{f}-\mathrm{t}}, P\right),\left(T_{\mathrm{a}-\mathrm{a}}\right.$, $P)$ and $\left(T_{\mathrm{r}}, P\right)$.

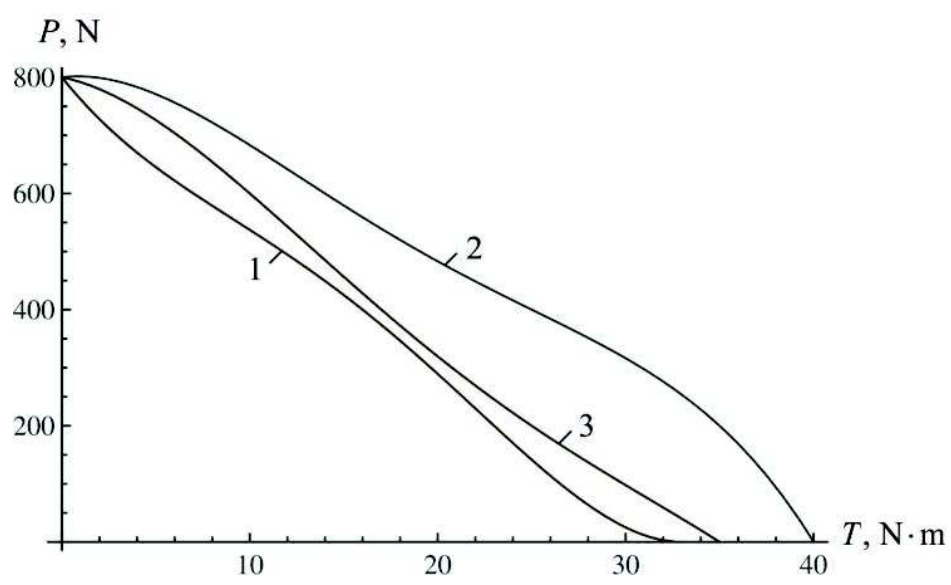

Fig. 5. Ultimate combinations of loading factors: human's own weight $P$ and bending moment $T_{\mathrm{f}-\mathrm{t}}$ for flexion-tension (curve 1), bending moment $T_{\mathrm{a}-\mathrm{a}}$ for adduction-abduction (curve 2 ) or torsion torque $T_{\mathrm{r}}$ (curve 3 )

The ultimate values of the human's own weight, the bending moments $T_{\mathrm{f}-\mathrm{t}}$, $T_{\mathrm{a}-\mathrm{a}}$ and the torque $T_{\mathrm{r}}$ corresponding to critical value of J-integral in the cases of, only a single load-applied to the operated bone are shown in Table 1. As reflected by the Figure 5 and Table 1, superposition of the bending moments or the torsion torque on the human's own weight is much more dangerous for a patient than action of their own weight. The most dangerous addition to the human's own weight for the studied type of the post-resection defect is that of the bending moment $T_{\mathrm{f}-\mathrm{t}}$ load while the least dangerous that of the bending moment $T_{\mathrm{a}-\mathrm{a}}$. Importantly, any additional load can cause a significant reduction of the allowed fraction of weight to be applied to the operated bone.

Table 1. Ultimate magnitudes of human's own weight bending moments and torque

\begin{tabular}{|l|l|}
\hline \multicolumn{1}{|c|}{ Type of loading } & \multicolumn{1}{c|}{ Ultimate magnitudes } \\
\hline Own weight $P, \mathrm{~N}$ & 800.0 \\
\hline Adduction-abduction moment $T_{\mathrm{f}-\mathrm{t}}, \mathrm{N} \cdot \mathrm{m}$ & 40.0 \\
\hline Flexion-tension moment $T_{\mathrm{a}-\mathrm{a}}, \mathrm{N} \cdot \mathrm{m}$ & 33.0 \\
\hline Torque $T_{\mathrm{r}}, \mathrm{N} \cdot \mathrm{m}$ & 35.0 \\
\hline
\end{tabular}

\section{Conclusions}

Finite-element calculations of the $J$-integrals were used to assess the ultimate combinations of loads (the human's own weight together with one of three types of loads - the flexion-tension moment, the adduction-abduction moment or 
the torque for the model of the femur bone after surgical resection. The postresection defect was in the middle third of the femur on its medial side. The obtained results showed that for defect with this location the most dangerous loads combination was of the human's own weight and $T_{\mathrm{f}-\mathrm{t}}$. Nearly the same danger is in the case of action of the weight and the torque $T_{\mathrm{r}}$. Based on FE simulations, for the post-resection defect with the studied dimensions, any weight in excess of $800 \mathrm{~N}$ is critical. For patients with lower weight a discharge regime can be recommended after surgery; if the weight is more than $800 \mathrm{~N}$, reinforcement of the femur bone would be viable; but even in the discharge regime flexiontension and torsion loads should be avoided. Obviously, some safety margin should be introduced to accommodate significant levels of uncertainty, e.g. dynamic load components. The critical values for the flexion-tension bending moment and the torque can be used to obtain ultimate rotation angles for a femur corresponding to onset of cracking near the post-resection defect. Based on these angles, more precise recommendations for implementing a discharge regime after surgical resection can be formulated for a patient. The approach to obtaining the ultimate loads (both for single and their combinations) applied on the femur bone with post-resection defect based on FE calculation of $J$-integrals presented in this study can be extended to post-resection defect with different sizes as well as to other long human bones (shank, humerus, radius and ulna of forearm).

\section{Acknowledgement}

The research leading to these results has received funding from the People Programme (Marie Curie International Research Staff Exchange) of the European Union's Seventh Framework Programme FP7/2007-2013/ under REA grant agreement n PIRSES-GA-2013-610547.

\section{References}

[1] Bessho M., Ohnishi I., Matsuyama J., Matsumoto T., Imai K. Nakamura K.: Prediction of strength and strain of the proximal femur by a CT-based finite element method, J. Biomech., 40 (2007) 1745-1753.

[2] Dall'Ara E., Luisier B., Schmidt R., Kainberger F., Zysset P., Pahr D.: A nonlinear QCT-based finite element model validation study for the human femur tested in two configurations in vitro, Bone, 52 (2013) 27-38.

[3] Derikx L.C., van Aken J.B., Janssen D., Snyers A., van der Linden Y.M., Verdonschot N., Tanck E.: The assessment of the risk of fracture in femora with metastatic lesions, J. Bone Joint Surg., British Vol., 94-B (2012) 1135-1142.

[4] Dijkstra P.D.S., Oudkerk M., Wiggers T.: Prediction of pathological subtrochanteric fractures due to metastatic lesions, Arch. Orthop. Trauma Surg., 116 (1997) 221 224.

[5] Elias J.J., Frassica F.J., Chao E.Y.S.: The open section effect in a long bone with a longitudinal defect - a theoretical modeling study, J. Biomech., 33 (2000) 15171522.

[6] Harrington K.D.: New trends in the management of the lower extremity metastases, Clinic. Orthop., 169 (1982) 53-61. 
[7] Hipp J.A., Edgerton B.C., An K.-N., Hayes W.C.: Structural consequences of transcortical holes in long bones loaded in torsion, J. Biomech., 23 (1990) 12611268.

[8] Hipp J. A., Springfield D.S. Hayes W.C.: Predicting pathologic fracture risk in the management of metastatic bone defects, Clinic. Orthop., 312 (1995) 120-135.

[9] Keyak J.H., Rossi S.A.: Prediction of femoral fracture load using finite element models: an examination of stress- and strain-based failure theories, J. Biomech., 33 (2000) 209-214.

[10] Keyak J.H., Rossi S.A., Jones K.A., Les C.M., Skinner H.B.: Prediction of fracture location in the proximal femur using finite element models, Med. Eng. Phys., 23 (2001) 657-664.

[11] Lee T.: Predicting failure load of the femur with simulated osteolytic defects using noninvasive imaging technique in a simplified load case, Annal. Biomed. Eng., 35 (2007) 642-650.

[12] Mirels H.: Metastatic disease in long bones: a proposed scoring system for diagnosing impending pathologic fractures, Clinic. Orthop., 249 (1989) 256-264.

[13] Ota T., Yamamoto I., Morito R.: Fracture simulation of the femoral bone using the finite-element method: How a fracture initiates and proceeds, J. Bone Min. Metabolism, 17 (1999) 108-112.

[14] Schileo E., Taddei F., Cristofolini L., Viceconti M.: Subject-specific finite element models implementing a maximum principal strain criterion are able to estimate failure risk and fracture location on human femurs tested in vitro, J. Biomech., 41 (2008),356-367.

[15] Spruijt S., van der Linden J. C., Dijkstra P.D.S., Wiggers T., Oudkerk M., Snijders C.J., van Keulen F., Verhaar J.A.N., Weinans H., Swierstra B.A.: Prediction of torsional failure in 22 cadaver femora with and without simulated subtrochanteric metastatic defects, Acta Orthopaed., 77 (2006) 474-481.

[16] Tanck E., van Aken J.B. van der Linden, Y.M., Schreuder H.W.B., Binkowski M., Huizenga H., Verdonschot N.: Pathological fracture prediction in patients with metastatic lesions can be improved with quantitative computed tomography based computer models, Bone, 45 (2009) 777-783.

[17] Tanne T., Sakuda M. Biomechanical and clinical changes of the craniofacial complex from orthopedic maxillary protraction, Angle Orthod., 61 (1991) 145-152.

[18] Van der Linden Y.M., Dijkstra P.D.S., Kroon H.M., Lok J.J., Noordijk E.M. Leer J.W.H., Marijnen C.A.M.: Comparative analysis of risk factors for pathological fracture with femoral metastases, J. Bone Joint Surg., British Vol., Vol. 86-B (2004) 566-573.

[19] Wedin R., Hansen B. H., Laitinen M., Trovik C., Zaikova O., Bergh P., Kalen A., Schwarz-Lausten G., Vult von Steyern F., Walloe A., Kellerand J., Rudiger J. W.: Complications and survival after surgical treatment of 214 metastatic lesions of the humerus, J. Shold. Elbow Surg., 21 (2012) 1049-1055.

[20] Li S.: Cutting of cortical bone tissue: analysis of deformation and fracture process, $\mathrm{PhD}$ thesis, Loughborough University, UK, 2013. 
[21] Letter to editor: ISB recomendation on definitions of joint coordinate ssytem of various joints for the reporting of human joint motion - part I: ankle, hip, and spine, J. Biomech., 35 (2002) 543-548.

[22] Yoshioka Y., Siu D., Cooke D.V., Chir B.: The anatomy and functional axes of the femur, J. Bone Join. Surg., 69-A, No. 6 (1987) 873-880.

\section{POWSTAWANIE MIKROPEKNIEĆ W POBLIŻU WAD CHIRURGICZNYCH KOŚCI UDOWEJ: OCENA WARUNKÓW OBCIĄŻEŃ NISZCZĄCYCH}

\section{Streszczen i e}

W artykule przedstawiono wyniki badań w których analizowano wady kości udowej o prostokątnym kształcie będące wynikiem resekcji chirurgicznej zmian nowotworowych. Na podstawie obliczeń metodą elementów skończonych całki $J$ w okolicy wady kości określono niszczące kombinacje obciążeń odpowiadające powstawaniu mikropęknięć. obciążenia odpowiadające jednoczesnemu obciążeniu kości przez ciężar człowieka, obciążenia ściskająco-rozciągające, odwodzenie i obrót kości udowej. Na podstawie uzyskanych wyników sformułowano zalecenia dotyczące zapobiegania patologicznemu złamaniu kości udowej z defektem chirurgicznym.

Słowa kluczowe: resekcja chirurgiczna, kość, całka J, mikropęknięcia, obciążenie złożone

DOI: $10.7862 / \mathrm{rm} .2016 .8$

Otrzymano/received: $12.05 .2016 \mathrm{r}$.

Zaakceptowano/accepted: 22.06.2016 r. 